\title{
Work from Home in The New Norm: Prospects and Challenges in Kabul, Afghanistan
}

\section{Mujeeb Ur Rehman Usman and Rohini Devi}

To Link this Article: http://dx.doi.org/10.6007/IJARBSS/v11-i9/11202

DOI:10.6007/IJARBSS/v11-i9/11202

Received: 05 July 2021, Revised: 27 July 2021, Accepted: 20 August 2021

Published Online: 26 September 2021

In-Text Citation: (Usman \& Devi, 2021)

To Cite this Article: Usman, M. U. R., \& Devi, R. (2021). Work from Home in The New Norm: Prospects and Challenges in Kabul, Afghanistan. International Journal of Academic Research in Business and Social Sciences, 11(9), 1612-1621.

\section{Copyright: (c) 2021 The Author(s)}

Published by Human Resource Management Academic Research Society (www.hrmars.com)

This article is published under the Creative Commons Attribution (CC BY 4.0) license. Anyone may reproduce, distribute, translate and create derivative works of this article (for both commercial and non-commercial purposes), subject to full attribution to the original publication and authors. The full terms of this license may be seen at: http://creativecommons.org/licences/by/4.0/legalcode

Vol. 11, No. 9, 2021, Pg. 1612 - 1621

Full Terms \& Conditions of access and use can be found at http://hrmars.com/index.php/pages/detail/publication-ethics 


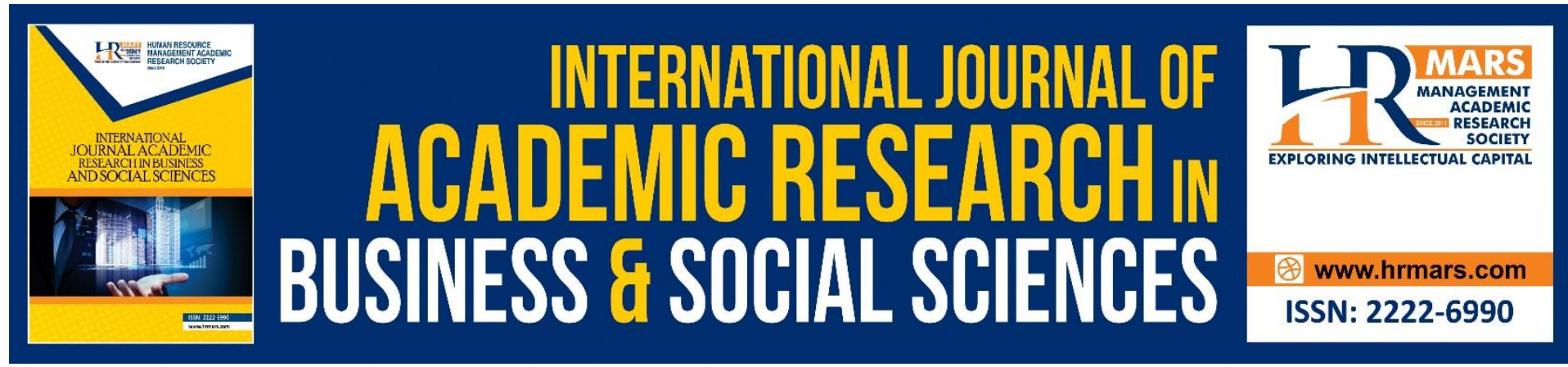

\title{
Work from Home in The New Norm: Prospects and Challenges in Kabul, Afghanistan
}

\author{
Mujeeb Ur Rehman Usman ${ }^{1}$ and Dr Rohini Devi ${ }^{2}$ \\ ${ }^{1} \mathrm{PhD}$ Researcher, Binary University of Management \& Entrepreneurship, Malaysia, \\ ${ }^{2}$ Professor and Deputy Vice Chancellor, Binary University of Management Entrepreneurship, \\ Malaysia
}

\begin{abstract}
Home working uncovered a swap scope of opportunities for the manner in which organizations can work and construction themselves. This examination means to research the possibilities and difficulties of individuals who face this possibility during Covid-19 pandemic and investigate the elements affecting the utilization of work from home in new standard among the two teachers and understudies in Kabul Afghanistan. This very examination focuses on telecommute in new standard possibilities and difficulties in agricultural nations, especially in Afghanistan. This examination consolidates with applied structure, utilizing both quantitative and subjective strategy for information assortment. Likewise, the information examination will be done later as it is reasonable investigation so the information will be gathered by arbitrary inspecting from 100 understudies and speakers in Kabul Afghanistan. The first work of the examination is the assortment of applicable direct data from specialists of both public and private organizations, for example, the executive's specialists utilizing an overview device. Fruitful execution and utilization of learning the executive's frameworks (LMSs) turned into a basic test for few schooling foundations during the Covid-19 pandemic. Rudders (Higher Education Learning Management System) might be a countrywide LMS utilized for instructing and picking up during the isolate period brought about by Coronavirus in Kabul colleges. As it was the essential experience of Kabul Universities in utilizing the preparation the executive's frameworks during the pandemic, challenges were relied upon to appear. No past research has been led on either examining the possibilities and difficulties of telecommuting in new standards during the Covid-19 pandemic in Kabul Afghanistan. Thus, there was no bound together perspective on the likely difficulties of possibilities and difficulties of telecommuting in new standard among the scientists.
\end{abstract}

Keywords: Pandemic, Work from Home, Learning Management System

\section{Introduction}

The startling flare-up of the (COVID-19) pandemic has influenced pretty much every area, including the advanced education establishments all throughout the planet (Adedoyin and Soykan, 2020). During this crucial point in time of the COVID-19 pandemic, a large portion of the nations all throughout the planet moved to internet educating (Bokayev et al., 2021). In the same way as other different nations all throughout the planet, the public authority of 
Afghanistan has likewise chosen to excuse every one of the instructive organizations to contain the tremendous spread of the COVID-19 pandemic (Orfan and Elmyar, 2020). Because of the conclusion of the multitude of scholastic establishments the nation over, the service of advanced education (MoHE) of Afghanistan chose to make up for the showing system through an internet instructing framework. Consequently, MoHE of Afghanistan planned and controlled an online stage framework called Higher Education Learning Management System (HELMS) to quickly react to the COVID-19 emergency in the instructive setting.

The change interaction of vis-à-vis instructing started to web-based showing where a great many educators and understudies were permitted to utilize this stage. From that point forward, the state funded colleges the nation over have encountered internet educating as the new marvel during the COVID-19 pandemic where there was no earlier groundwork for such a crisis case.

During the most recent twenty years in certain pieces of the world, web-based instructing has developed and changed significantly because of different reasons (Bayrak et al., 2020). School and college speakers are keener on educating and learning with online methodologies where the learning system should be possible more at a lower cost (Green, 2010). Plus, Green (2010) expressed that web-based instructing can give more chances of setting aside time and cash since nobody drive to look for information.

Notwithstanding this developing revenue in web-based educating, understudies' fulfilment level remaining parts the most thought marker of web-based instructing experience. Understudies' fulfilment level can be connected to an assortment of elements, including understudy's instructor's cooperation, understudy's association, course appraisal quality, web quality, self-viability, and understudies' learning cycle (Harsasi and Sutawijaya, 2018; Kirtman, 2009). Subsequently, internet showing assumed an essential part during this basic circumstance of the pandemic and acquired a twofold standing.

Thus, one of the influenced results of COVID-19 can be the scholastic exhibition of understudies as they experience their first endeavour towards internet instructing and, in this way, their degree of fulfilment from web-based educating can likewise be important to be estimated. To address the meaning of web-based instructing in such crisis cases, the current examination intended to explore the impacts of COVID-19 on the scholarly execution of Afghan understudies and their fulfilment level with web- based educating during the COVID19 episode. Furthermore, this examination sorts out the critical distinction in the scholarly execution of Afghan understudies alongside their degree of fulfilment across sexual orientation. Plus, the connection between the scholarly exhibition of understudies and their degree of fulfilment with internet educating is inspected. For this reason, the scientist defined the accompanying exploration inquiries to arrive at these objectives.

(1) Is there any impact (positive or negative) of the COVID-19 on the scholarly execution of Afghan understudies?

(2) To what degree are the Afghan understudies happy with web-based instructing during the COVID-19 episode?

(3) Is there any critical contrast in the scholarly execution of Afghan understudies across sex?

(4) Is there any critical distinction in their degree of fulfilment with web-based educating across sexual orientation?

(5) Is there any connection between the scholarly exhibition of Afghan understudies and the revealed level of fulfilment with internet instructing? 


\section{Review of Related Works}

Albeit very few investigations have been finished investigating the impacts of COVID-19 on the scholastic execution of understudies and evaluating their degree of fulfilment with webbased educating during the episode of COVID-19, however the analyst attempted to discover the most related examinations concerning the current examination. Deplorably, the episode of COVID-19 influenced enormously practically every one of the instructive levels in various settings across the globe and have been consolidated into the instructive settings to have conceivable arrangement for instructors and understudies (Oyinloye, 2020). An examination led by Gonzalez, Rubia, et al (2020) analyzed the effects of COVID-19 restriction on the presentation of understudies at the advanced education level. They utilized field trial research with 458 students by two gatherings: control and test. Shockingly, their exploration uncovered that COVID-19 constringent left a positive effect on the exhibition of the understudies and assisted them with upgrading the learning systems of the understudies. Essentially, one more investigation was done by Realyvásquez-Vargas et al (2020) investigated whether the natural elements influence understudies' scholastic presentation during COVID19. To do this examination, they found that understudies' scholastic exhibition has been influenced by natural elements during the COVID-19 pandemic.

Besides, Elhadary et al (2020) assessed the effects of COVID-19 on the scholarly execution of science and sociology understudies in Turkey. Their discoveries showed that many components influenced the scholastic execution of the understudies during the COVID-19 emergency.

In spite of that, their investigation additionally uncovered that the two educators and understudies are happy with the utilization of web-based learning and instructing. Loton et al (2020) considered web-based picking up during the COVID-19 pandemic with their fulfilment and execution. The aftereffect of their discoveries showed that there is a critical effect on the two exhibitions of the understudies and their degree of fulfilment with web-based educating and getting the hang of during the COVID-19 episode. In like manner, one more examination directed in Indonesian setting where the scientist investigated the arrangement, benefits, and imperatives with internet picking up during the COVID-19 pandemic. They have talked about their member's fulfilment on the exhibition of the understudies during the COVID-19 episode (Fatoni et al., 2020).

Consequently, in view of the previously mentioned investigates completed on the impacts of COVID-19 on the exhibition of understudies, one can induce that there is an extraordinary effect of COVID-19 on the scholastic execution of understudies accessible in the writing.

Concerning the fulfilment level of understudies with internet instructing during the COVID-19 pandemic, many investigations have been finished by numerous specialists. An examination led by Almusharraf and Khahro (2020) researched the level of understudies' fulfilment with internet getting the hang of during the flare-up of COVID-19. The aftereffect of their examination uncovered that every one of the members were significantly happy with internet learning apparatuses and stages. Their examination additionally showed that understudies were happy with the help given by staff during the COVID-19 emergency. While one more investigation was directed in Kazakhstan to investigate distance learning and the guardians' fulfilment during the COVID-19 pandemic of the instructive quality. Their discoveries show that guardians' degree of fulfilment with web-based learning is emphatically connected, while numbers in youngsters have contrarily related as per the general inclination of guardians with internet learning stages during the COVID-19. 
Generally, their fulfilment with the nature of web-based learning is significantly sure (Bokayev et al., 2021). The discoveries of an examination uncovered by Baber (2020) are in accordance with the demonstrated investigations where the analyst discovered a decidedly incredible degree of fulfilment in giving web-based educating. Conversely, the discoveries of the examination uncovered by Sharma et al (2020) demonstrated that most of their respondents are disappointed with web-based learning stages. Additionally, the discoveries of an examination uncovered by Dinh and Nguyen (2020) show that web-based educating and learning had a lower fulfilment level than vis-à-vis instructing.

Additionally, numerous different examinations investigated the degree of fulfilment with internet instructing during the COVID-19 pandemic in different settings and tracked down a significant degree of fulfilment with web-based educating, (Chen et al., 2020; Choe et al., 2019; Fatani, 2020). Then again, Alanazi et al (2020) examined innovation fulfilment and understudies' exhibition in online courses. They revealed that there was a more vulnerable connection between understudies' presentation and innovation fulfilment in online courses. While there was one more investigation completed in China by Chen et al (2020) examining understudies' fulfilment level with internet instructing during the episode of COVID-19. The discoveries of their investigation showed no immediate impacts found on understudies' fulfilment by close to home variables, while the accessibility of online applications greatest affected understudies' fulfilment level. In spite of all examinations on fulfilment level, different analysts announced high fulfilment level of understudies with web-based instructing during the COVID-19 flare-up (Ali et al., 2011; Bauk et al., 2014; Coman et al., 2020; Johnston et al., 2005; Naziya and Khan, 2020; Roach and Lemasters, 2006; Sharma et al., 2020; Surahman and Sulthoni, 2020). Startlingly, very few examinations have been found with low or disappointment in web-based educating during the COVID-19 pandemic. Shockingly, there were likewise no investigations found analysing the sex contrasts in the scholastic execution of understudies and just as contrasts in the degree of fulfilment across sexual orientations with internet educating during the COVID-19 emergency.

Considering that Afghanistan is one of the low-pay nations all throughout the planet alongside less foundation of ICT at the state funded colleges (McMahon et al., 2020; Noori et al., 2020). Web-based educating and learning as another wonder stayed unacquainted to the understudies and a large portion of the instructors (Hashemi, 2020). Absence of instructive preparing in utilizing mechanical gadgets and applications, the significant expense of Wi-Fi, and absence of power with a lack of gadgets for giving internet showing conditions are the critical hindrances towards online schooling. Consequently, during the pandemic of COVID19 in Afghanistan, numerous difficulties and disappointment, and vulnerability of the application with web-based instructing were accounted for. In view of individual encounters, the vast majority of the understudies didn't take an interest in the online meeting and their commitment in the online classes was so powerless. Then again, the vulnerability of utilizing applications and stages made the understudies to be befuddled with regards to partaking in web-based educating meetings. For instance, HELMS was presented by the MoHE of Afghanistan as the elective application and stage reacting to COVID-19, yet all things considered, the majority of the educators were able to show their understudies through Google Classroom, WhatsApp, or potentially other online Media's foundation. This vulnerability of utilizing the stages lead the understudy to be disappointed and definitely influenced their presentation in web-based instructing.

In spite of that, it was additionally detailed that female understudies were not able to partake in the online meetings and didn't achieve the relegated task because of some terrible culture 
or potentially disparity as far as having the means to purchase electronic gadgets like a PC, versatile as well as pay the expense of web. As indicated by Orfan (2021), these circumstances are considered because of the impediment and social standards limit that exists in Afghan culture. These imbalances in getting to the gadgets and applications influenced the scholarly execution of understudies during the flare-up of the COVID-19 emergency in certain pieces of the nation and by all means disappointed understudies from web-based instructing. Be that as it may, internet instructing plays had a urgent impact in the advanced education organizations of Afghanistan during the COVID-19 pandemic, many examinations have been done to research the impacts of COVID-19 on the scholastic accomplishments of understudies around the world. Sadly, no examinations have been done to investigate the impacts of COVID-19 on the scholastic execution of Afghan understudies and their degree of fulfilment with internet educating. In such manner, the momentum study is an endeavour to take out this examination hole to investigate whether COVID-19 influenced the understudies' presentation and are they happy with web-based educating the nation over. This examination is likewise critical on the ascent to the writing in Afghanistan setting and just as to give experiences to MoHE of Afghanistan, specialists, and understudies to improve their readiness of such crisis cases later on.

\section{Methodology}

The momentum research study utilized a quantitative examination plan in which a review survey was adjusted to look at the impacts of COVID-19 on the scholastic exhibition of understudies and their degree of fulfilment with web-based educating. The got information were examined through spellbinding and inferential factual investigation. The analyst utilized clear insights to distinguish the recurrence, rate, the mean, and standard deviation of the respondents' segment profile just as to quantify their degree of fulfilment with web-based educating. While the inferential insights were utilized to look at the distinctions in the scholarly exhibition of understudies and their degree of fulfilment with web-based educating across sexual orientation just as to sort out the connection among execution and fulfilment level.

\section{Participants}

The current examination was completed in Afghanistan where every one of the respondents $(\mathrm{N}=100)$ including 36 female and 64 male understudies took an interest in the investigation from public and private colleges.

Their ages ran somewhere in the range of 18 and 32 years of age. The determination cycle of the examining was utilized through the straightforward irregular testing method to guarantee that each example has an equivalent shot at being chosen in the examination.

\section{Data Collection Instruments}

The specialist planned the overview poll dependent on the writing examined. There were around 41 things adjusted from crafted by (Almazova et al., 2020; Almusharraf et al., 2020; Elhadary et al., 2020). The poll comprises of three areas planned with five focuses Likert scale going from 1 to unequivocally differ to 5 to emphatically concur. The principal segment of the poll was zeroing in on the segment profile of the understudies containing five things. Segment 2 of the survey containing 18 things planned to look for the scholastic presentation of the understudies. The third part of the survey containing 18 things centres around the understudies' degree of fulfilment with internet instructing during the COVID-19 flare-up. To 
lead this exploration study, the specialist made an interpretation of the poll into Dari language since English is an unknown dialect and the majority of the understudies can't communicate in English.

\section{Validity and Reliability}

To really take a look at the legitimacy, the survey was shipped off two specialists of examination in the workforce of language and writing at Kabul University. The master's ideas and remarks were fused and considered in the survey for additional improvement. For the dependability of everything, the analyst led a pilot concentrate among 26 understudies from various colleges.

\section{Data Collection Procedure}

The review survey was managed through Google structures. The connection of the survey was shared through the web-based media stages (Facebook, WhatsApp, and Twitter) with a greeting letter. It was shared multiple times on my Facebook page by the understudies and companions freely. It was additionally shipped off some of college speakers mentioning them to impart the poll to their understudy gatherings. The respondents were offered 3 days to finish and response the poll. Furthermore, the protection and privacy matter were referenced in the assent structure guaranteeing the respondents that the gave data must be utilized for research purposes.

\section{Result and Discussion}

The current examination pointed toward exploring chiefly the impacts of the COVID-19 pandemic on the scholastic presentation of Afghan understudies, existing difficulties and their degree of fulfilment with internet instructing. Plus, it additionally endeavoured to investigate the connection between scholastic exhibitions of understudies with their degree of fulfilment during the COVID-19 flare-up. In such manner, as indicated by the discoveries, an overall inquiry was posed by the respondents to assess their inclinations of showing mode (on the web or up close and personal). Henceforth, the discoveries of the examination in this regard uncovered that practically the entirety of the respondents liked to have vis-à-vis educating, while less respondents liked to have internet instructing. The discoveries of the investigation are in accordance with the examinations led by (Beltekin and Kuyulu, 2020; Surahman and Sulthoni, 2020) whose discoveries uncovered that online showed course was not as successful as up close and personal instructing. As such, their respondents favored up close and personal educating over web-based instructing. In contrast to this discovering, the discoveries of studies led by (Khan et al., 2021; Novikov, 2020) uncovered that web-based educating for its opportunity and usability had been liked over eye to eye instructing during the COVID-19 episode. This might represent the adverse consequences of COVID-19 on understudies' scholastic exhibition.

\section{Conclusion}

The current examination pointed toward exploring the impacts of COVID-19 on the scholastic exhibition of Afghan understudies and to recognize how much are the Afghan understudies happy with internet instructing in the Afghanistan setting. The examination additionally looked to investigate whether there is any huge distinction in the scholastic exhibition of Afghan understudies and their degree of fulfilments with internet educating across sexual orientation. Likewise, the connection between the scholarly exhibition of understudies and 
their degree of fulfilment has additionally been analysed. Accordingly, the discoveries uncovered that COVID-19 adversely influenced the scholastic exhibition of Afghan understudies. It was likewise tracked down that Afghan understudies were profoundly disappointed with web-based instructing during the COVID-19 emergency. The discoveries showed that there was a huge distinction in the scholastic presentation of Afghan understudies across sex, just as a huge contrast in the degree of fulfilment with web-based educating was found across sex. At long last, a solid positive relationship was distinguished between scholastic execution and their degree of fulfilment with web-based educating. This is the principal study examining the impacts of COVID-19 on the scholastic presentation of Afghan understudies and investigating their degree of fulfilment with web-based instructing across Afghanistan. A significant strength of this investigation is its huge example size of 100 alongside its enormous setting among public and private colleges in Afghanistan. Consequently, the discoveries of the investigation present a few ramifications and ideas for the MoHE and other included gatherings for them to upgrade both the quality and limit of internet instructing during sudden and crises and, from another side, to invigorate the understudies' scholarly exhibition and to work on their degree of fulfilment with web-based educating. Hence, it is suggested for the MoHE and every one of the elaborate partners to give web-based showing applications, give proficient preparing to web-based showing applications and gadgets, give Wi-Fi offices, give modest web bundles, and give virtual assets. Likewise, it is prescribed for instructors to give intelligent and thorough online administrations alongside strong direction and useful criticism that could improve the understudies' degree of fulfilment with internet educating. As the finding of this examination concerning the connection between scholarly exhibition and fulfilment level showed a positive relationship, it is shown that low presentation brings about high disappointment with internet educating.

\section{References}

Adedoyin, O. B., \& Soykan, E. (2020). Covid-19 pandemic and online learning: The challenges and opportunities. Interactive Learning Environments, 1-13.

Alanazi, A. A., Frey, B. B., Niileksela, C., Lee, S. W., Nong, A., \& Alharbi, F. (2020). The role of task value and technology satisfaction in student performance in graduate-level online courses. TechTrends, 64(6), 922-930. https://doi.org/10.1007/s11528-02000501-8

Ali, A., Ramay, M. I., \& Shahzad, M. (2011). Key factors for determining student satisfaction in distance learning courses: A study of Allama Iqbal Open University (AIOU) Islamabad, Pakistan. Turkish Online Journal of Distance Education, 12(2), 114-127. https://doi.org/10.17718/tojde.10766

Almazova, N., Krylova, E., Rubtsova, A., \& Odinokaya, M. (2020). Education sciences challenges and opportunities for Russian higher education amid COVID-19: Teachers' perspective. Education Sciences, 10(204). https://doi.org/10.3390/educsci10120368

Almusharraf, N. M., \& Khahro, S. H. (2020). Students' satisfaction with online learning experiences during the COVID-19 pandemic. International Journal of Emerging Technologies in Learning, 15(21), 246-267. https://doi.org/10.3991/ijet.v15i21.15647

Aristovnik, A., Keržič, D., Ravšelj, D., Tomaževič, N., \& Umek, L. (2020). Impacts of the COVID19 pandemic on the life of higher education students: A global perspective. Sustainability (Switzerland), 12(20), 1-34. https://doi.org/10.3390/su12208438 
Baber, H. (2020). Determinants of students' perceived learning outcome and satisfaction in online learning during the pandemic of COVID19. Journal of Education and E-Learning Research, 7(3), 285-292. https://doi. org/10.20448/journal.509.2020.73.285.292

Babinčáková, M., \& Bernard, P. (2020). Online experimentation during covid-19 secondary school closures:Teaching methods and student perceptions. Journal of Chemical Education, 97(9), 3295-3300. https://doi.org/10.1021/acs.jchemed.0c00748

Bauk, S., Šćepanović, S., \& Kopp, M. (2014). Estimating students' satisfaction with web-based learning system in blended learning environment. Education Research International, 2014(1) 1-11. https://doi.org/10.1155/2014/731720

Bayrak, D. F., Moanes, D. M., \& Altun, D. A. (2020). Development of online course satisfaction scale. Turkish Online Journal of Distance Education, 21(4), 110-122. https://doi.org/10.17718/TOJDE.803378

Beltekin, E., \& Kuyulu, I. (2020). The effect of Coronavirus (Covid19) outbreak on education systems: Evaluation of distance learning system in Turkey. Journal of Education and Learning, 9(4), 1. https://doi.org/10.5539/jel.v9n4p1

Bolliger, D. U., \& Wasilik, O. (2009). Factors influencing faculty satisfaction with online teaching and learning in higher education. Distance Education, 30(1), 103-116. https://doi.org/10.1080/01587910902845949

Choe, R. C., Scuric, Z., Eshkol, E., Cruser, S., Arndt, A., Cox, R., ... Crosbie, R. H. (2019). Student satisfaction and learning outcomes in asynchronous online lecture videos. CBE Life Sciences Education, 18(4), 1-14. https://doi.org/10.1187/cbe.18-08-0171

Devon, E. M., Gregory, A. P., Louise, C. I., \& F., E. (2020). Global resource shortages during COVID-19: Bad news for low-income countries. PLOS, 12-14(7), 1-3. https://doi.org/10.1371/journal.pntd.0008412

Di Pietro, G., Biagi, F., Costa, P., Karpiński, Z., \& Mazza, J. (2020). The likely impact of COVID19 on education: Reflections based on the existing literature and recent international datasets (Vol. 30275). Publications Office of the European Union.

Elhadary, T., Elhaty, I. A., Mohamed, A. A., \& M., A. (2020). Evaluation of academic performance of science and social science students in Turkish Universities during COVID-19 Crisis. Journal of Critical Reviews, 7(11), 1740-1751. https://doi.org/10.31838/jcr.07.11.280

Fatani, T. H. (2020). Student satisfaction with videoconferencing teaching quality during the COVID-19 pandemic. BMC Medical Education, 20(1), 1-8. https://doi.org/10.1186/s12909-020-02310-2

Fatoni, A., Nurkhayati, N., Nurdiawati, E., Fidziah, E., Pamungkas, G., \& Azizi, E. (2020). University students online learning system during Covid-19 pandemic: Advantages, constraints, and solutions. Systematic Reviews in Pharmacy, 11(7), 570-576. https://doi.org/10.31838/srp.2020.7.81

Francisco, G. G., Jorge, G., Martin, O. R., \& Motero, M. A. A. (2012). Gender differences in Elearning Satisfaction. Computers \& Education, 58(1), 283-290.

Green, K. C. (2010). The campus computing survey. The Campus Computing Project. http://www.campuscomputing.net/2010-campus-computing-survey

Khan, M. A., Vivek, Nabi, M. K., Khojah, M., \& Tahir, M. (2021). Students' perception towards e-learning during the covid-19 pandemic in India: An empirical study. Sustainability, 13(1), 1-14. https://doi.org/10.3390/su13010057 
Kirtman, L. (2009). Online versus in-class courses: An examination of differences in learning outcomes. Issues in Teacher Education, 18(2), 103-116. https://eric.ed.gov/?id=EJ858508

Loton, D., Parker, P., Stein, C., \& Gauci, S. (2020). Remote learning during COVID-19: Student satisfaction and performance.EdArXiv,7 (3),1-9https://doi.org/10.35542/osf.io/n2ybd

Mcwherter, S. (2017). The effects of teacher commitment on student achievement. International Journal of Social Sciences \& Educational Studies, 3(3), 51-54. https://doi.org/10.23918/ijsses.v3i3p51

Mirjeta, S., Beqiri, N., Chase, M., \& Atena, B. (2009). Online Course Delivery: An Empirical Investigation of Factors Affecting Student Satisfaction. Journal of Education for Business, 851, 95-100. doi:10.1080/08832320903258527

Nguyen, V. A. (2016). Examining students' satisfaction with online learning activities in blended learning course: A case study. ICERI2016 Proceedings, 1(November), 3155-3164. https://doi.org/10.21125/iceri.2016.1716

Online teaching and learning in higher education during the coronavirus pandemic: Students' perspective. Sustainability, 12 (24), 1-22. https://doi.org/10.3390/su122410367

Orfan, S. N., \& Elmyar, A. H. (2020). Public knowledge, practices and attitudes towards covid19 in Afghanistan. Public Health of Indonesia, 6(4), 104-115. https://dx.doi.org/10.36685/phi.v6i4.356

Shahzadi, E., \& Ahmad, Z. (2011). A study on academic performance of university students. 8th International Conference on Recent Advances in Statistics, (October), 255-268. https://doi.org/10.13140/2.1.3949.3126

Sintema, E. J. (2020). Effect of COVID-19 on the performance of grade 12 students: Implications for STEM education. Eurasia Journal of Mathematics, Science and Technology Education, 16(7), 1-6. https://doi.org/10.29333/ejmste/7893

Surahman, E. (2020). Student Satisfaction toward Quality of Online Learning in Indonesian Higher Education During the Covid-19 Pandemic. In 2020 6th International Conference on Education and Technology (ICET) (pp. 120-125). IEEE.

The impact of the COVID-19 pandemic on user experience with online education platforms in China. Sustainability. 12(18), 1-31 https://doi.org/10.3390/SU12187329

Tosta, M. R. (2012). Measurement of satisfaction with the online and classroom teaching methodologies of graduate students and its implications for academic achievement. Scientific International Journal, 9 (3), 15-31. http://www.nperci.org/M.ReyesSatisfactionV9N3.pd 